\title{
Thermomodernization of buildings with the utilization of green walls
}

\author{
Małgorzata Wesołowska ${ }^{1, *}$, and Marta Laska $^{1}$ \\ ${ }^{1}$ Wroclaw University of Science and Technology, Faculty of Environmental Engineering, \\ Wybrzeże Wyspiańskiego 27, 50-370 Wrocław, Poland
}

\begin{abstract}
The revitalization of historical buildings is a subject that is increasingly being discussed around the world. This is connected with the goal set by the European and thus Polish and local policy to reduce energy consumption in existing buildings. The publication presents an unconventional solution for thermal modernization of buildings with the utilization of green walls. The article presents the literature and legal acts review on green walls, their construction and impact on existing buildings. It describes the benefits and disadvantages resulting from the use of vegetation on the external walls. Additionally the possibility of using green walls at the historic facility located in Wroclaw (Poland) is presented.
\end{abstract}

\section{Introduction}

The construction sector is one of the largest energy consumers, not only in Europe, but also in the world [1]. Increasing emphasis is placed on reducing its consumption which leads to improvement of the environment quality, especially lowering the level of pollution in the atmosphere. For this purpose the European Parliament and the Council established the Directive on the energy performance and efficiency of buildings [2] (EPBD). This legal act relates to existing buildings, including historical buildings.

The article presents below the possibilities of utilization of vegetation on external walls as a non-conventional solution of existing buildings in urban area. The historic post-industrial facility, located in Wroclaw (Poland), being under the conservation protection is described as the example of such a solution. The issue associated with the use of vegetation on the walls, which may give a number of benefits, in particular for the urban tissue, are broadly described.

\subsection{Thermomodernization}

The majority of buildings in Europe are residential buildings, accounting for around $75 \%$ of the total floor space area of building stock [3]. Almost $40 \%$ of them are over 50 years old [4]. The literature [3] describes also the statistics of non-residential buildings where three quarters of the service floor area is covered by offices $(30 \%)$, wholesale $(27 \%)$ and education (16\%). The Wroclaw's communal records of monuments itself has over 10000 positions [5]. Many of these facilities require renovations, due to high energy consumption, a state

* Corresponding author: malgorzata.wesolowska@pwr.edu.pl 
threatening the health or life of people staying in them and surrounded area, and to preserve cultural heritage.

Modernization of buildings is often connected with change of their functions and thus may lead to change in the requirements for indoor conditions. This results in the necessity of complex thermomodernization that may include the insulating the walls and roofs, improving the windows or glazing, modernization or changing the HVAC installation or the heat and cool source for high-efficiency systems, if it is technically, functionally and economically feasible [2], and also utilization of "solutions based on nature" such as green walls [2]. Possibilities of revitalization of such objects can be found in the literature [6,7].

There are [8] three important aspects of facilities modernization, namely economic, environmental and social. The first one arises from the fact that historic buildings are constructed in old technologies and follow, much less restrictive regulations in terms of energy consumption, material used and thermal resistance of building envelope and air tightness. This results in high energy consumption and operating costs. The environmental aspect is closely related to the economic one, as higher energy performance of building leads to lower amount of energy needed for building operation and thus reduction of the pollution. The last - the social dimension of building modernization, is strictly connected with the improvement of building indoor conditions that influences the level of satisfaction from the thermal environment of building users their health and productivity [9]. Additionally green walls and roofs are recommended to strengthen the effect of well-being and relaxation of occupants $[10,11]$.

The fundamental activity leading to the thermal improvements is based on lowering heat losses through the building envelope and protection from overheating. When the buildings being under cultural heritage are taken under consideration and the historic preservation officer take care of the building, the traditional insulation techniques cannot be applied. Therefore the utilization of green walls and roofs seem to be the most desirable solution in renovation process. Solutions based on nature have also additional positive effect on the surrounded urban area in terms of lowering the local air pollution and noise level, increasing shading effect and counteracting the formation of urban heat islands.

\section{Historic buildings under national and European law}

In every European city with a rich past one can find historic buildings. It is usually assumed that a building with more than 50 years of existence, while maintaining integrity with the time, style and historical value, can be considered as a monument $[1,4]$.

The revitalization of the protected buildings in Poland and their surroundings have to follow the guidelines of the voivodship Conservator of Monuments, which are based on the polish law acts [12]. All decisions regarding interference in the facility should be made to preserve its historical elements. For this reason, thermomodernization measures may be considerably limited. Historic buildings are divided into four classes [13] as follows: class I includes buildings in which architectural details have been preserved, so their parts require a special protection; class II includes objects that do not require special care, where details have not been preserved; buildings with historical significance and architectural values as well as buildings located in architecturally protected areas belonging to class III; non-historic buildings constitute to class IV.

One of the main issues addressed in [2] is the financing of renovation projects. The cost of buildings renovations in 2006 amounted to 302 million EUR and was only 20 million EUR lower than the founds designated to new residential buildings [8]. Therefore, following [2] the Member States should put a special emphasis to support all activities, which can lead to lower energy consumption of existing buildings and support the research on new solutions to improve energy performance of historic buildings. 


\section{Green walls}

Large cities in Europe improve in accordance with sustainable development. This idea applies to the use of vegetation on the facades of buildings, which nowadays is experiencing a renaissance. It is also conducive to leveling urban heat islands. The largest Polish cities, also strive to maintain as many green areas as possible. The efforts are visible in the acts of local law [14]. Krakow allocated the founds to support the development of small forms of greenery. The City Council of Wroclaw decided to exempt its residents from the real estate tax, when a biological cover with appropriate area was used on the partitions [15].

Restrictions related to conservation protection in many cases result in the lack of consent for the use of external thermal insulation composite systems. These enforce the need to use internal wall insulation (IWI) and thus to reduce the usable space, or other solutions like these indicated in the point 17 of the directive [2]. The publication draws attention to the use of natural solutions, namely green roofs and walls, as they have a positive impact on both, the building itself and the increase of thermal insulation resistance of external walls and thus the lowering the energy consumption of the building.

\subsection{Construction of green walls}

The green walls can be divided into two main categories due to their construction, namely green façades and living walls, Fig. 1.

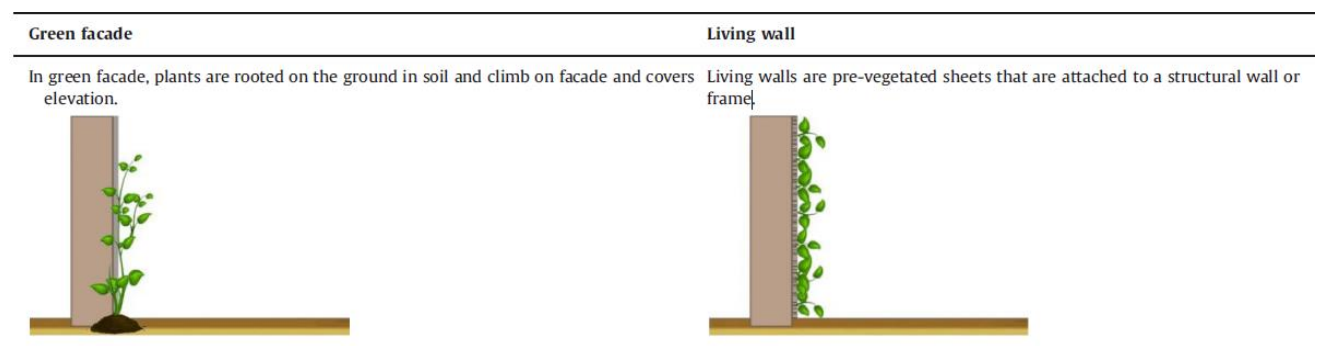

Fig. 1. Dichotomy of vertical greenery systems [16].

The main difference between these two solutions is the location of the plant substrate. The first assumes that climbing plants are rooted at the foot of the wall. The green façade vegetation climbs on the supporting structures directly or indirectly on the façade [17]. In the second solution the soil substrate in living walls is located in dedicated boxes on the entire surface of the façade. Therefore it requires supporting elements and the irrigation system, and thus is more expensive in comparison to green facades. Additionally the weight of living walls is within the range of $60-500 \mathrm{~kg} / \mathrm{m}^{2}[18]$.

\subsection{Vegetation}

The choice of plants for green walls depends on many factors. The main differences result from the construction of the wall and the local climate conditions. When green facades are under consideration it is necessary to plant vines, while for living walls heather vegetation should be planted. The list of plants suitable for Polish conditions is presented in Table 1. 
Table 1. Plants used in green facades in a temperate climate and Polish conditions [19].

\begin{tabular}{|c|c|c|c|c|}
\hline No. & Polish name & English name & Latin name & Requirements \\
\hline 1. & $\begin{array}{l}\text { winobluszcz } \\
\text { trójklapowy }\end{array}$ & creeper tricuspidata & $\begin{array}{c}\text { Parthenocissus } \\
\text { tricuspidata }\end{array}$ & \multirow{5}{*}{$\begin{array}{l}\text { No requirement of } \\
\text { supports or frames. } \\
\text { The plants have the } \\
\text { ability to "stick" to } \\
\text { the wall. }\end{array}$} \\
\hline 2. & $\begin{array}{c}\text { winobluszcz } \\
\text { pięciolistkowy }\end{array}$ & $\begin{array}{c}\text { creeper } \\
\text { quinquefolia }\end{array}$ & $\begin{array}{c}\text { Parthenocissus } \\
\text { quinquefolia }\end{array}$ & \\
\hline 3. & bluszcz pospolity & ivy & Hedera helix & \\
\hline 4. & hortensja pnąca & climbing hydrangea & $\begin{array}{l}\text { Hydrangea } \\
\text { petiolaris }\end{array}$ & \\
\hline 5. & milin & dropmore sp. & Campsis sp. & \\
\hline 6. & glicyna & glycine & Wisteria sp. & \multirow{4}{*}{$\begin{array}{l}\text { The plants circle } \\
\text { around vertical } \\
\text { elements, lines } \\
\text { stretched on supports } \\
\text { and appropriate } \\
\text { frames. }\end{array}$} \\
\hline 7. & wiciokrzew & honeysuckle & Lonicera sp. & \\
\hline 8. & dławisz & celastros & Celastrus sp. & \\
\hline 9. & chmiel & hop & Humulus sp. & \\
\hline 10. & $\begin{array}{c}\text { winobluszcz } \\
\text { zaroślowy }\end{array}$ & thicket creeper & $\begin{array}{c}\text { Parthenocissus } \\
\text { inserta }\end{array}$ & \multirow{7}{*}{$\begin{array}{l}\text { The plants climb on } \\
\text { rigid supports with } \\
\text { steel or wooden rods. } \\
\text { They attaches } \\
\text { themselves to the wall } \\
\text { with special } \\
\text { mustaches and } \\
\text { petioles. }\end{array}$} \\
\hline 11. & aktinidia & aktinidia & Actintdia $s p$. & \\
\hline 12. & kokornak & aristoloehia & Aristolochia sp. & \\
\hline 13. & rdest & fallopius & Fallopa sp. & \\
\hline 14. & męczennica & passifora & Passifora sp. & \\
\hline 15. & winnik & ampelopsis & Ampelopsis sp. & \\
\hline 16. & powojnik & clematis & Clematis sp. & \\
\hline
\end{tabular}

In addition, insolation is very important factor. A north wall is suitable for flowers that do not have excessive lighting requirements due to the prevailing partial shade and shade. The southern façade is exposed to direct solar radiation and thus high temperature. The façade facing east is suitable for most plants, mainly those that bloom and prefer the gentle sun exposure. The western one is ideally suited for blooming flowers due to the presence of sharp sun and high temperatures in the afternoon [20].

\subsection{Advantages of green walls}

The use of vegetation on the walls brings a number of benefits. This is especially important for heavily urbanized areas and with a dense network of urban tissue. In the case of historic buildings, it is often the only solution approved by the monument conservator.

\subsubsection{Environmental benefits}

The most important features of plants is the absorption of pollutants, called natural air filtration, and production of the oxygen. The photosynthesis leads to lowering the impact of the greenhouse effect in the urban area [16], the temperature, especially in the city centers 
and minimize the risk of heat island phenomenon occurrence. The Fig. 2. presents the temperature distribution in the area of impact walls with direct, indirect façade greenery and living wall system. Vegetation has a larger albedo (the light reflection coefficient) than most building materials, and thus can absorb more solar radiation heat instead of reflecting it [21].

a)

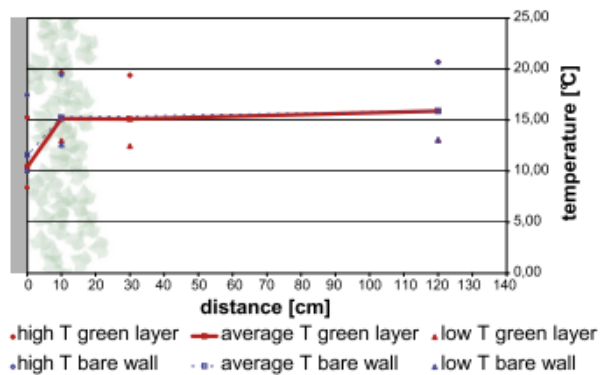

b)

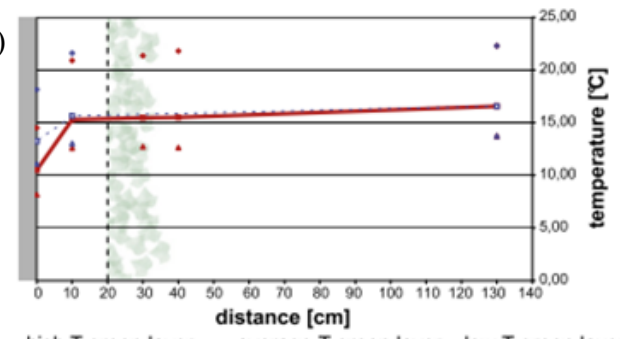

.high $\mathrm{T}$ green layer _-average $\mathrm{T}$ green layer . low $\mathrm{T}$ green layer .high $\mathrm{T}$ bare wall ... average $\mathrm{T}$ bare wall .low $\mathrm{T}$ bare wall

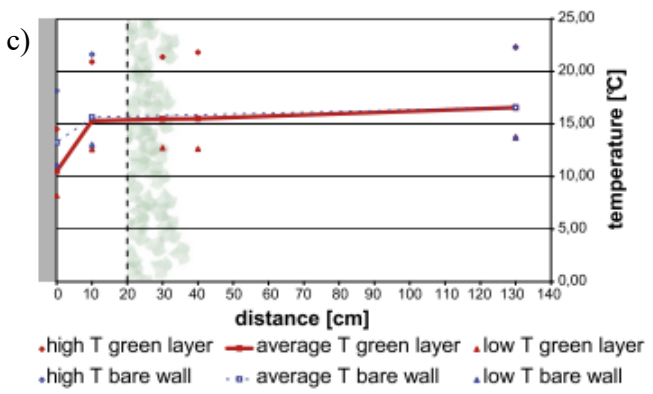

Fig. 2. The temperature distribution for: different types of green walls: a) direct façade greenery, b) indirect façade greenery, c) living wall system [22].

\subsubsection{Energy savings}

As aforementioned, the green wall acts as a thermal insulation for a building. The applied vegetation is a solar filter, absorption of sunlight during the reaction of photosynthesis and evapotranspiration is a process of heat reduction $[18,21]$. In the literature, one can find the studies showing the temperature differences using a green façade with ivy and without, reaching even $30 \mathrm{~K}$ [23]. This results in reducing the energy demand for cooling in the summer.

Table 2. The influence of a biological cover on the heat transfer coefficient for an external wall [23].

\begin{tabular}{|c|c|c|}
\hline \multicolumn{2}{|c|}{$\begin{array}{c}\text { Coefficient of heat transfer through the external wall, } \\
\mathbf{U}\left[\mathbf{W} / \mathbf{m}^{\mathbf{2}} \cdot \mathbf{K}\right]\end{array}$} & $\begin{array}{c}\text { Indicator for improving } \\
\text { wall insulation } \\
{[\%]}\end{array}$ \\
\hline Without plant cover & With climbing plants & 3.12 \\
\hline 0.32 & 0.31 & 5.56 \\
\hline 0.54 & 0.51 & 6.45 \\
\hline 1.24 & 1.16 & 15.53 \\
\hline 2.06 & 1.74 & 18.58 \\
\hline 2.53 & 2.06 & \multicolumn{2}{c}{} \\
\hline
\end{tabular}

The use of evergreen plant species also gives benefits in the winter, which is presented in Table 2. The table lists the heat transfer coefficients for partitions, which does not have a vegetation cover and where the $35 \mathrm{~cm}$ of ivy is applied. A significant improvement in insulation performance is particularly visible for partitions having an initial high heat transmittance coefficient (U). The vegetation, used to build green walls, also has a positive effect on the moisture level of the wall and thus its physical condition and indoor humidity. 
It also prevents against scattering rain and protects the wall against dampness that has direct impact on the heat transfer coefficient, and hence the energy needed to heat the building [23].

\subsubsection{Social benefits}

In the past, green walls were used to improve the attractiveness of the buildings. It has been known for centuries that closeness to nature has a positive effect on the humans psyche and improves their well-being. Greenery also improve the microclimate, air quality and create the sound barrier inside buildings and in their surrounded area $[16,23]$.

\subsection{Disadvantages of green walls}

Apart number of advantages the green solutions are not free from imperfections. Uncontrolled development of the biologically active cover may cause overgrowing of gutters and window openings. Thus such a façade need special and regular care. One should also take into consideration the patchy foliage of plants, which may affect thermal losses and the increased risk of moisture penetration. In addition, some creepers have a slow increase, which makes the effectiveness of green facades grow with their age. Also the designing of green walls is particularly important and need to consider proper plant choice and its correct arrangement [19].

\section{The vegetation on the existing buildings}

Wroclaw is a city with a rich history. In its area one can find the number of buildings being under the conservation protection and thus has a great potential in utilization of the solutions based on greenery. The following part of the paper describes the possibility of using green walls on the post-industrial building from the beginning of the $20^{\text {th }}$ century being under protection of the conserver officer [24].

\subsection{Thermomodernization of external walls}

The exemplary building, due to the historic importance cannot be insulated with the traditional methods. The use of IWI system is questionable as there would be necessity to interfere in the valuable internal surfaces and would be connected with the increased risk of water condensation.
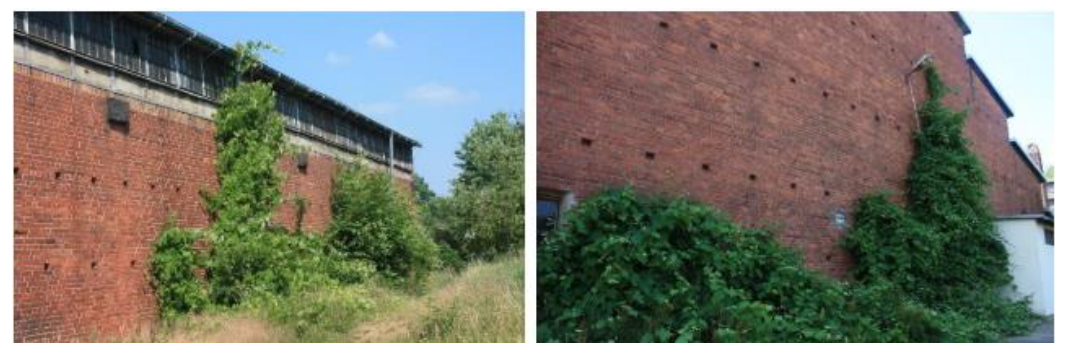

Fig. 3. Facade of the considered building (photo: M. Wesołowska) [21].

Therefore the implementation of the green facade is recognized as an appropriate solution and without negative influence on the valuable history wall. The solution is safe for construction and in accordance with the local spatial development plan imposing the condition of maintaining a biologically active area. 
The inventory of the building has shown that two of the walls cannot be used as the green walls, due to the presence of a gates and waste storage. The designated area that could be covered with vegetation is over $400 \mathrm{~m}^{2}$ on the southern wall and about $230 \mathrm{~m}^{2}$ on the east. This gives the total potential of $650 \mathrm{~m}^{2}$ of green insulation.

\subsection{Thermal analysis}

As a result of the calculations, the insulation of vertical walls in the building was determined. The value of the heat transfer coefficient varies from $1.2 \mathrm{~W} / \mathrm{m}^{2} \cdot \mathrm{K}$ to $2.0 \mathrm{~W} / \mathrm{m}^{2} \cdot \mathrm{K}$. The largest surface of the external walls is a partition with $\mathrm{U}$-value of $1.2 \mathrm{~W} / \mathrm{m}^{2} \cdot \mathrm{K}$. Following the literature (see Table 2), due to lack of external insulation, application of green climbing plants can bring the improvement in this heat transfer coefficient even more than $6 \%$ and lower its value to about $1.16 \mathrm{~W} / \mathrm{m}^{2} \cdot \mathrm{K}$. The improvement of the thermal insulation maybe is not spectacular and will bring the heating cost reduction about 1000 PLN per annum, however the investment costs of the solution are negligible and additional advantages during the summer season and the environmental impact are unquestioned.

The vegetation will cause a reduction in the surface temperature of the wall. Depending on the adopted green façade solution, it is possible to lower it to even $1.7^{\circ} \mathrm{C}$ [18]. This, in turn, can have a positive effect on indoor comfort temperature, lowering the cool demand and, if AC system is applied, lowering energy costs.

\section{Summary}

Thermomodernization of buildings with the utilization of green facades is particularly important issue for buildings under monument protection. Applying both direct and indirect systems, there is no need to interfere in the wall with traditional thermal insulation methods. These activities will not cause the loss of the historical value of the building. It is safe option for the historic façades.

The use of vegetation on the walls gives a number of benefits. The biggest one is the reduction of heat and cool demand and thus the energy consumption of the building by increasing the insulation of the external walls. This solution improves moisture condition of the wall and thus has a positive effect on the building construction itself and quality of indoor air. In addition, the reduction of carbon dioxide and improvement of external air quality is particularly important for urban areas. Vegetation helps to eliminate the effects of the urban heat island, which is an increasing problem in dense urban tissue.

The work was partially financed by The Faculty of Environmental Energy, Wroclaw University of Science and Technology, Poland. Ref no. 0401/0055/18. The authors woud like to thank to Tratwa Association.

\section{References}

1. L. Mazzarella, Energy Build. 95, 23-31 (2015)

2. Dyrective of the European Parliament ond of the Council, 844 (2018)

3. https://ec.europa.eu/energy/en/eu-buildings-factsheets. (Accessed: 29th January 2019)

4. A. L. Webb, Renew. Sustain. Energy Rev. 77, 748-759 (2017)

5. BIP Urzędu Miejskiego Wrocławia, Gminna Ewidencja Zabytków Miasta Wrocławia. Available at: http://bip.um.wroc.pl/artykuly/204/zabytki-wroclawia. (Accessed: 20th February 2019) 
6. M. Baborska-Narożny, Czas. Tech. Archit. 12, 275-279 (2012)

7. S. Kaczmarek, Social aspects of reconstruction of old industrial regions in Europe, Prace naukowe Uniwersytetu Śląskiego w Katowicach, 1722, 120-126 (1998)

8. D. Anastaselos, E. Giama, A. M. Papadopoulos, Energy Build. 41, 1165-1171 (2009)

9. M. Laska, E3S Web of Conf., 17, 00050 (2017)

10. M. Mansor, I. Said, I. Mohamad, Asian J. Environ.-Beh. Stud. 2 (2017)

11. M. Demuzere, J. Environ. Manage. 146, 107-115 (2014)

12. Ustawa z dnia 23 lipca 2003 r. o ochronie zabytków i opiece nad zabytkami, Dz.U. 2003 Nr 162 poz. 1568

13. M. Drozdowicz, M. Laska, Rynek Instal. 10, 1-6 (2016)

14. Plan adaptacji miasta Krakowa do zmian klimatu do roku 2030

15. UCHWAŁA RADY MIEJSKIEJ WROCŁAWIA w sprawie zwolnień od podatku od nieruchomości powierzchni użytkowych lokali mieszkalnych $w$ ramach projektu intensyfikacji powstawania terenów zieleni w obrębie Miasta Wroctawia, XV/268/15

16. T. Safikhani, A. M. Abdullah, D. R. Ossen, M. Baharvand, Renew. Sustain. Energy Rev. 40, 450-462 (2014)

17. A. B. Besir, E. Cuce, Renew. Sustain. Energy Rev. 82, 915-939 (2018)

18. E. Cuce, Appl. Energy, 194, 247-254 (2017)

19. E. Trzaskowska, Teka Kom. Arch. Urb. Stud. Kraj. - OL PAN VI, 110-121 (2010)

20. A. Kania, Zasady projektowania i wykonywania zielonych dachów i żyjących ścian. Poradnik dla gmin. SWISS CONTRIBUTION, 91 (2013)

21. G. Pérez, J. Coma, I. Martorell, L. F. Cabeza, Renew. Sustain. Energy Rev. 39, 139-165 (2014)

22. K. Perini, M. Ottelé, A. L. A. Fraaij, E. M. Haas, R. Raiteri, Build. Environ. 46, 2287-2294 (2011)

23. D. Fabianowski, Zieleń miejska, 8 (2011)

24. M. Wesołowska, Building energy audit and analysis of possibility of using green facades improving condition and humidity of the object, praca magisterska (Wroclaw University of Science and Technology, 2018) 